\title{
Morphological characterization and physiological potential of Stenachaenium megapotamicum (Spreng.) Baker seeds ${ }^{1}$
}

\author{
Mariana Grassi Noya ${ }^{2 *}$, Francine Lorena Cuquel $^{2}$, Maristela Panobianco ${ }^{2}$
}

\begin{abstract}
Stenachaenium megapotamicum (Spreng.) Baker is a native species with ornamental potential for use in landscaping and floral arrangements. This study aimed to evaluate germination and storage of $S$. megapotamicum seeds. In addition, the seeds were characterized morphologically. Germination was tested under constant $\left(10,15,20\right.$ and $\left.25^{\circ} \mathrm{C}\right)$ and alternating $\left(15-20^{\circ} \mathrm{C}\right)$ temperatures. The seeds were stored inside two types of packages (kraft paper and polyethylene bags) under 5 and $18^{\circ} \mathrm{C}$ for six months. Water content, germination speed index, and thousand seed weight were measured. The fruits are botanically named cypselae; seed coat and fruit wall are juxtaposed and inseparable; the exalbuminous seeds are $4.8 \mathrm{~mm}$ long, $1.7 \mathrm{~mm}$ wide and $0.4 \mathrm{~mm}$ thick, on average. Germination temperature at $20{ }^{\circ} \mathrm{C}$ under constant light was considered optimal. Cypselae can be stored for six months in kraft paper or polyethylene bags at 5 or $18{ }^{\circ} \mathrm{C}$, resulting in above $80 \%$ germination.
\end{abstract}

Index terms: Asteraceae, physiological quality, germination, morphology.

\section{Caracterização morfológica e avaliação do potencial fisiológico de sementes de Stenachaenium megapotamicum (Spreng.) Baker}

\begin{abstract}
RESUMO -Stenachaenium megapotamicum (Spreng.) Baker é uma espécie nativa com potencial ornamental, para uso em paisagismo e arranjos florais. Objetivou-se com este trabalho efetuar a caracterização dos aspectos morfológicos, avaliar a germinação e o potencial de armazenamento de suas sementes, visando subsidiar a propagação. No estudo de germinação testaram-se temperaturas constantes $\left(10,15,20\right.$ e $\left.25^{\circ} \mathrm{C}\right)$ e alternada $\left(15-20^{\circ} \mathrm{C}\right)$. Para o armazenamento, utilizaram-se embalagens do tipo Kraft e embalagens polietileno, mantidas nas temperaturas de 5 e $18{ }^{\circ} \mathrm{C}$ durante seis meses. Realizaram-se, também, a determinação do teor de água, índice de velocidade de germinação, massa de mil sementes e a caracterização morfológica das sementes. Os frutos são do tipo cipsela, o tegumento da semente e a parede do fruto são justapostos e indissociáveis, a semente é exalbuminosa, tendo em média, 4,8 mm de comprimento, 1,7 mm de largura e 0,4 $\mathrm{mm}$ de espessura. A temperatura de germinação de $20^{\circ} \mathrm{C}$, na presença de luz constante, foi considerada ótima. As cipselas podem ser armazenadas por até seis meses em embalagens do tipo Kraft ou polietileno, a 5 ou $18^{\circ} \mathrm{C}$, mantendo germinação acima de $80 \%$.
\end{abstract}

Termos para indexação: Asteraceae, qualidade fisiológica, germinação, morfologia.

\section{Introduction}

Native plants are widely used in floriculture and landscaping, because they are more adapted to the ecosystem than exotic plants. However, little research on seed morphology and seed quality has been undertaken. Seed quality is associated with effective seedling production because it can increase the profitability of such activity (Alves et al., 2008), provided that high-quality physiological material is used. Sexual reproduction is usually faster, easier and lowcost (Marcos-Filho, 2005); it is particularly advantageous to producers of ornamental plants because it saves space and allows for easier transportation and storage (Grolli, 2008). Reproduction by seeds is also important for the conservation of the genetic variability of the species (Stefenon et al., 2008).

Identifying optimal conditions of temperature, light, packaging and time for seed storage (Melo et al., 2007) is crucial to maintain the physiological potential of the seeds from sowing to harvest, so that seedling production can be properly planned. In addition, knowledge of seed morphology is useful for accurate species identification (Ilkiu-Borges and Mendonça, 2009), especially in seed banks (Silva et al., 2012).

The species Stenachaenium megapotamicum (Spreng.) Baker belongs to the family Asteraceae; it is a sub shrub

${ }^{1}$ Submitted on 09/19/2012. Accepted for publication on 02/28/2013.

${ }^{2}$ Universidade Federal do Paraná, Departamento de Fitotecnia e Fitossanitarismo, Caixa Postal 19461, 80035-050 - Curitiba, PR, Brasil.

*Corresponding author $<$ contato@marianagrassi.com> 
with ornamental potential. It occurs spontaneously in the field ecosystems in southern Brazil and in secondary vegetation (Stumpf et al., 2009), and it is adapted to the subtropical climate. It has golden colored fruits and capitulum inflorescence (Figure 1A), both of which are very attractive to wildlife. It can be used alone or in clusters and also in fresh or dehydrated floral arrangements (Stumpf et al., 2009). It is an alternative to exotic plants commonly used in landscaping in southern Brazil.
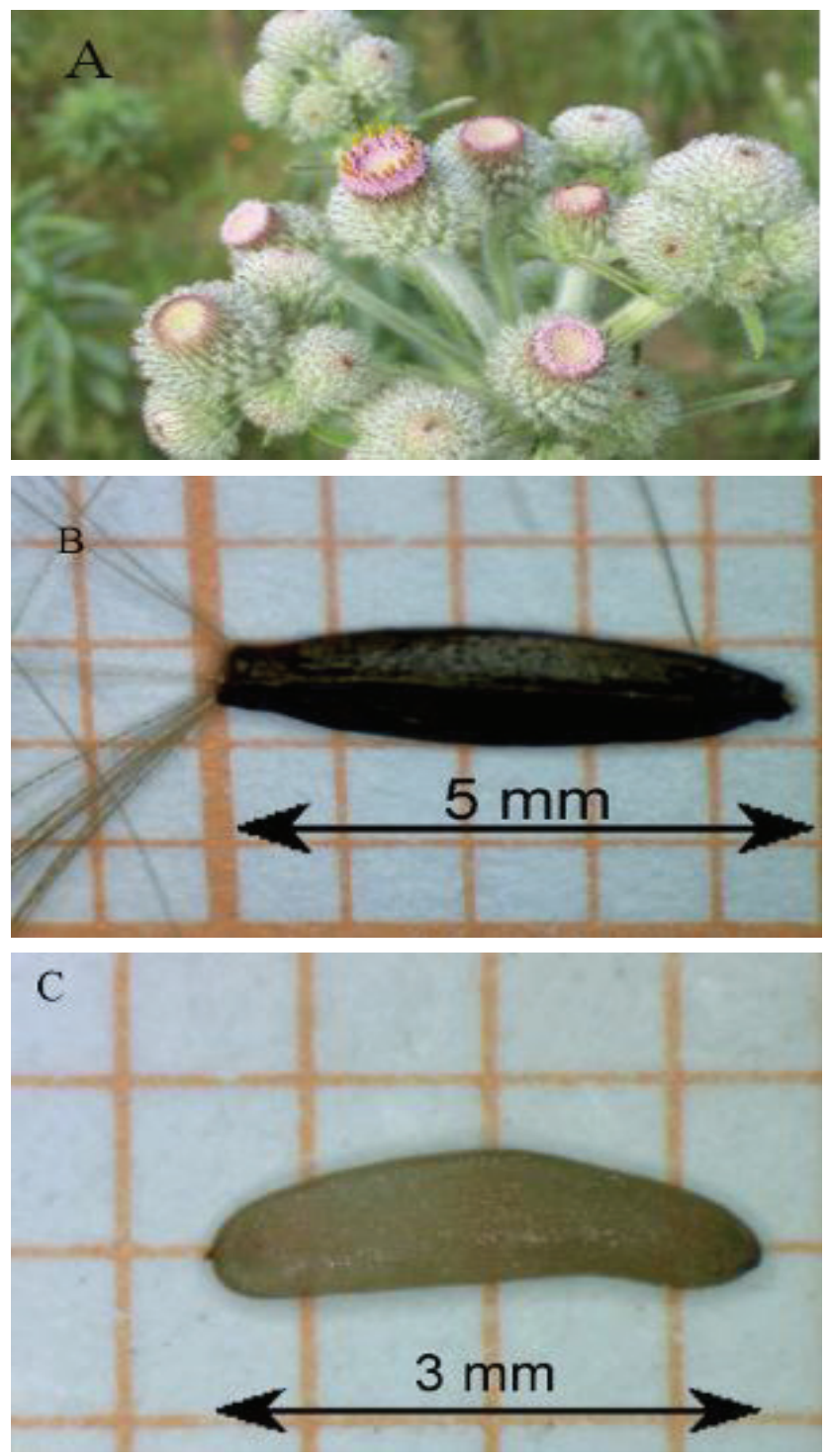

Figure 1.Inflorescence (A), cypsela (B) and seed embryo (C) of Stenachaenium megapotamicum (Spreng.) Baker.

Aspects of seed technology for S. megapotamicum seeds are unknown in the scientific community. Thus, the objective of this research was to characterize S. megapotamicum seeds morphologically (externally and internally) and evaluate their germination and storage potential.

\section{Material and Methods}

S. megapotamicum seeds were collected from 30 plants located in the municipality of Tapes $\left(30^{\circ} 40\right.$ ' 22 " south latitude and $51^{\circ} 23^{\prime} 45^{\prime \prime}$ west longitude), Rio Grande do Sul, in April 2010, when they were dark brown (37 days after flowering) and breaking off the mother plant. After collection, the seeds were taken to the Seed Analysis Laboratory, Department of Plant Science and Plant Health of the Federal University of Paraná. The seeds were divided into four subsamples (replicates) and stored in Kraft paper s in an environment with temperature between 5 and $7{ }^{\circ} \mathrm{C}$ and relative humidity of $90 \%$ until the beginning of the experiments, when the following assessments were conducted:

Water content: assessed by oven drying at $103 \pm 2{ }^{\circ} \mathrm{C}$ for $17 \pm$ $1 \mathrm{~h}$ (Brasil, 2009), using two replicates of about $0.100 \mathrm{~g}$ each; the results were expressed in percentage terms (wet basis).

Germination test: four replicates of 50 seeds were sown in transparent plastic boxes $(11.0 \times 11.0 \times 3.5 \mathrm{~cm})$ on two sheets of blotting paper, previously moistened with an amount of water equivalent to 2.5 times the weight of the dry substrate (Brasil, 2009).The following temperatures were tested: 10, 15,20 and $25{ }^{\circ} \mathrm{C}$ under constant light; and $15-20^{\circ} \mathrm{C}$ under alternating light (photoperiod of $8 \mathrm{~h}$ at $20^{\circ} \mathrm{C}$ and $16 \mathrm{~h}$ in the dark at a temperature of $15{ }^{\circ} \mathrm{C}$ ). The number of normal seedlings was counted daily from emergence, from the $6^{\text {th }}$ to the $13^{\text {th }}$ day, when germination ceased.

Germination speed index (GSI): assessed together with germination, and determined according to the mathematical expression proposed by Maguire (1962).

One thousand seed weight: eight replicates of 100 seeds taken from the pure seed portion were used. Variance, standard deviation and coefficient of variation were calculated, based on the requirements of the Rules for Seed Testing (Brasil, 2009).

To evaluate storage, fruits from 300 matrices of $S$. megapotamicum were collected in May 2011. They had been planted at the Center for Experimental Units of the Federal University of Paraná, in the municipality of Pinhais $\left(25^{\circ}\right.$ 23 '30" South latitude and 49 07'30" West longitude). Fruits were collected from plants $1.70 \mathrm{~m}$ tall, at the time they were dark brown and breaking off the plants ( 42 days after flowering). The seeds were stored for 180 days in two types of packages: 0.1-mm thick Kraft paper bags and transparent polyethylene bags, in environments with two different temperatures ( 5 and $\left.18^{\circ} \mathrm{C}\right)$. For each storage period $(0,60,120$ and 180 days $)$, the following were assessed: germination temperature of $20{ }^{\circ} \mathrm{C}$ under constant light ( $40 \mathrm{~W}$ fluorescent lamp) with count of normal seedlings being held at six and 13 days after the start of the test, and water content of the seeds, as described 
above. The study was implemented in a factorial design $(4 \times 2 \times 2)$ consisting of four storage times $(0,60,120$ and 180 days), two packages (Kraft paper and polyethylene bags) and two temperatures $\left(5\right.$ and $\left.18{ }^{\circ} \mathrm{C}\right)$.

For the morphological description of the seeds, the following variables were analyzed: external variables included color, dimensions (length, width and thickness), texture and consistency of the integuments; internal variables were type of embryo (cotyledons, hypocotyl-radicle axis, plumule), shape, location and presence or absence of endosperm (Silva et al., 2008). For embryo visualization, 50 seeds were placed in boiling water for five minutes, so that they could break off the fruit. The dimensions (length, width and thickness) of 100 seeds were obtained with a digital caliper, and the respective measurements were used to calculate average, standard deviation and coefficient of variation. The images were obtained with the aid of a MiView USB microscope Version 1.00.

The results were subjected to analysis of variance and the means were compared by Tukey's test at $5 \%$ probability, after the storage data were transformed into $\arcsin \sqrt{\frac{x}{100}}$.

\section{Results and Discussion}

It was found that the fruits of $S$. megapotamicum are dry, indehiscent (Figure 1B), cypselae (because they come from inferior ovary) and dark brown, and they have double pappus with small bristles on the outer layer. According to Marzinek et al. (2008), cypsela corresponds to a type of monospermic, dry, indehiscent fruit in which the seed coat and fruit wall are juxtaposed and inseparable, which is why all the tests have been developed with the seeds enclosed in the fruits. The seeds are clavate-shaped and yellowish white; their outer surface is glossy, striate, membranous and exalbuminous.

The embryo (Figure 1C) is surrounded by a gelatinous, whitish membranaceous coat in a straight, axial-spatulate position, with a short and cylindrical hypocotyl-radicle axis. The cotyledons are foliaceous, thin, long and obovate with a rounded apex. The seeds showed average length of $4.79 \mathrm{~mm}( \pm 0.38)$, width of 1.68 $\mathrm{mm}( \pm 0.39)$ and thickness of $0.42 \mathrm{~mm}( \pm 0.28)$. The thousand seed weight was $0.119 \mathrm{~g}$, and initial water content was $11.0 \%$.

Temperatures that showed the highest efficiency were 15 and $20{ }^{\circ} \mathrm{C}$ under continuous light, reaching up to $94 \%$ germination. However, when the alternate temperature $15-20{ }^{\circ} \mathrm{C}$ was used, with $16 \mathrm{~h}$ of darkness, germination zero was obtained (Table 1), indicating that the seeds of this species probably had a positive photoblastic response. In positive photoblastism, the light effects are beneficial and aimed at the synthesis of hormones and enzymes, respiratory control, permeability of the integument to oxygen and lipid metabolism (Marcos-Filho, 2005). It should be noted that various combinations of temperatures in the absence of light were tested preliminarily, but no germination was observed, which is why such data were not included in the study.

The temperature at which germination occurs can influence both total germination and germination speed (Table 1) because temperature has an effect on water absorption and biochemical reactions that determine the metabolism of germination (Carvalho and Nakagawa, 2000). Thus, it is crucial to gather information on the temperature, or temperature range, at which germination occurs at maximum efficiency, i.e., the highest germination occurs within the shortest possible time.

The results for GSI (Table 1) show that the temperature of $20{ }^{\circ} \mathrm{C}$ was optimal (best) to assess the viability of $S$. megapotamicum seeds because it offers maximum germination with greater speed, i.e., higher average number of normal seedlings per day.

Table 1. Seed germination and germination speed index (GSI) of Stenachaenium megapotamicum (Spreng.) Baker, at different temperatures.

\begin{tabular}{lcc}
\hline Temperature $\left({ }^{\circ} \mathrm{C}\right)$ & Germination $(\%)$ & GSI \\
\hline 10/ light & $0 \mathrm{~b}^{*}$ & $0.0 \mathrm{c}$ \\
15/ light & $94 \mathrm{a}$ & $6.5 \mathrm{~b}$ \\
20/ light & $94 \mathrm{a}$ & $10.2 \mathrm{a}$ \\
25/ light & $0 \mathrm{~b}$ & $0.0 \mathrm{c}$ \\
15-20 (16h dark/ 8h light) & $0 \mathrm{~b}$ & $0.0 \mathrm{c}$ \\
\hline C.V. (\%) & 10.5 & 7.8 \\
\hline
\end{tabular}

*Means followed by the same letter do not differ by Tukey's test at $5 \%$ probability.

When storage was assessed, no interaction was observed between any of the three factors analyzed, and the germination percentages were similar in the first four months of storage (Table 2). After this period, germination was reduced to $80 \%$. As for packaging (Table 2), no difference was observed between Kraft paper and polyethylene, both of which can be used by producers to maintain germination above $80 \%$ (Table 2). In a study by Santana and Carvalho (2006), it was also found that seeds of another Asteraceae (Baccharis trimera) showed similar results for a period of seven months when stored in three types of packaging: paper heavier than $50 \mathrm{~g}$, polyethylene plastic and glass.

The seeds behaved similarly for storage temperature, both at $5^{\circ} \mathrm{C}$ and $18^{\circ} \mathrm{C}$ (Table 2), without significant loss of quality. This feature allows for seed storage to take place under less technical conditions, similar to those found in most commercial nurseries.

The water content of the seeds during storage remained low, ranging from $8.3 \%$ to $10.9 \%$ (Table 3), which allowed adequate storage at the two temperatures investigated in this study. 
Table 2. Seed germination (cypselae) of Stenachaenium megapotamicum (Spreng.) Baker, stored for different periods of time, with different types of packaging and temperature.

\begin{tabular}{cc}
\hline Time (months) & Germination (\%) \\
\hline 0 & $94 \mathrm{a}^{*}$ \\
2 & $94 \mathrm{a}$ \\
4 & $88 \mathrm{ab}$ \\
6 & $80 \mathrm{~b}$ \\
\hline C. V. $(\%)$ & 4.7 \\
\hline Packaging & Germination $(\%)$ \\
\hline Kraftpaper & $90 \mathrm{a}$ \\
Polietileno & $84 \mathrm{a}$ \\
\hline C. V. $(\%)$ & 9.6 \\
\hline Temperatures $\left({ }^{\circ} \mathrm{C}\right)$ & Germination $(\%)$ \\
\hline 5 & $90 \mathrm{a}$ \\
18 & $85 \mathrm{a}$ \\
\hline C. V. $(\%)$ & 6.1 \\
\hline
\end{tabular}

*Means followed by the same letter do not differ by Tukey's test at $5 \%$ probability.

Table 3.Water content of Stenachaenium megapotamicum (Spreng.) Baker seeds (cypselae) during storage at different temperatures and types of packages.

\begin{tabular}{lccrc}
\hline \multirow{2}{*}{ Storage conditions } & \multicolumn{4}{c}{ Storage time } \\
\cline { 2 - 5 } & $\begin{array}{c}\text { meses } \\
\text { months }\end{array}$ & $\begin{array}{c}4 \\
\text { months }\end{array}$ & $\begin{array}{c}6 \\
\text { months }\end{array}$ \\
\hline & \multicolumn{4}{c}{$\%$} \\
\hline $18^{\circ} \mathrm{C} /$ Kraft & $11.0 \mathrm{a}$ & $10.9 \mathrm{a}$ & $10.9 \mathrm{a}$ & $10.7 \mathrm{a}$ \\
$18^{\circ} \mathrm{C} /$ Polyethylene & $11.0 \mathrm{a}$ & $9.6 \mathrm{a}$ & $9.3 \mathrm{a}$ & $9.1 \mathrm{a}$ \\
$5^{\circ} \mathrm{C} /$ Kraft & $11.0 \mathrm{a}$ & $8.8 \mathrm{~b}$ & $8.5 \mathrm{~b}$ & $8.3 \mathrm{~b}$ \\
$5^{\circ} \mathrm{C} /$ Polyethylene & $11.0 \mathrm{a}$ & $10.3 \mathrm{a}$ & $10.2 \mathrm{a}$ & $10.1 \mathrm{a}$ \\
\hline C. V. $(\%)$ & 0.0 & 8.6 & 8.6 & 8.6 \\
\hline
\end{tabular}

\section{Conclusions}

S. megapotamicum has cypsela dry fruit, with seeds juxtaposed with the fruits, length of $4.8 \mathrm{~mm}$, width of $1.7 \mathrm{~mm}$ and thickness of $0.4 \mathrm{~mm}$.

The germination test should be conducted at $20{ }^{\circ} \mathrm{C}$ under constant light, with counts performed on the sixth and $13^{\text {th }}$ day after sowing.

The seeds can be stored for up to six months in Kraft paper or polyethylene bags at 5 and $18{ }^{\circ} \mathrm{C}$, resulting in germination percentage above $80 \%$.

\section{Acknowledgments}

We would like to thank the "Fundação Araucária" for their financial support and REUNI for granting masters scholarships during this research.

\section{References}

ALVES, E.U.; NASCIMENTO, C.D.L.; BRUNO, R.L.A.; ALVES, A.U.; BRAGA JÚNIOR, J.M.; CARDOSO, E.A.; GALINDO, E.A.; SILVA, K.B. Germinação e vigor de sementes de Bauhinia divaricata L. Revista Ciência Rural, v.38, n.4, p.960-966, 2008.http://www.scielo.br/scielo. php?pid=s0103-84782008000400009\&script=sci_arttext.

BRASIL. Ministério da Agricultura, Pecuária e Abastecimento. Regras para análise de sementes. Ministério da Agricultura, Pecuária e Abastecimento. Secretaria de Defesa Agropecuária. Brasília: MAPA/ACS, 2009. 395p.http:// www.bs.cca.ufsc.br/publicacoes/regras\%20analise\%20sementes.pdf

CARVALHO, N.M.; NAKAGAWA, J. Sementes: ciência, tecnologia e produção. Jaboticabal: FUNEP, 2000. 588p.

GROLLI, P.R. Propagação de plantas ornamentais. In: PETRY, C. Plantas ornamentais: aspectos para a produção. Passo Fundo: Ed. Universidade de Passo Fundo, 2008. Cap.4, p.59-69.

ILKIU-BORGES, F.I.; MENDONÇA, M.S. Morfologia da semente de Bauhinia monandra Kurz. (Leguminosae-Caesalpinoideae). Revista Brasileira de Sementes, v.31, n.4, p.168-174, 2009.http://www.scielo.br/scielo. php?script=sci_arttext\&pid=s0101-31222009000400020\&lng=en\&nrm=iso.

MAGUIRE, J.D. Speed of germination - aid in selection and evolution for seedling emergence and vigor. Crop Science, v.2, n.2, p.176-177, 1962.

MARCOS-FILHO, J. Fisiologia de sementes de plantas cultivadas. Piracicaba: FEALQ, 2005. 495p.

MARZINEK, J.; PAULA, O.C.; OLIVEIRA, D.M.T. Cypselaorachene? Refining terminology anatomical and historical factors.Revista Brasileira de Botânica, v.31, n.3, p.549-553, 2008.http://www.scielo.br/scielo. php?script=sci_arttext\&pid=S0100-84042008000300018\&lng=en\&nrm=iso.

MELO.; P.R.B.; OLIVEIRA, J.A.; PINTO, J.E.B.P.; CASTRO, E.M.; VIEIRA, A.R.; EVANGELISTA, J.R.E. Germinação de aquênios de arnica (Lychnophora pinaster Mart.) armazenados em diferentes condições. Ciência e Agrotecnologia, v.31, n.1, p.75-82, 2007.http://www.scielo.br/scielo. php?script $=$ sci_arttext\&pid $=$ s1413-70542007000100012\&lng=en\&nrm=iso

SANTANA, A.M.S.; CARVALHO, R.I.N. Viabilidade e capacidade de armazenamento de sementes de carqueja coletadas em três municípios no Paraná. Scientia Agraria, v.7, n.1, p.15-20, 2006.http://redalyc.uaemex.mx/ src/inicio/artpdfred.jsp?icve $=99516263002$.

SILVA, K.B.; ALVES, E.U.; BRUNO, R.L.A.; MATOS,V.P.; GONÇALVES, E.P. Morfologia de frutos, sementes, plântulas e plantas de Erythrina velutinaWilld.,Leguminoseae - Papilionideae. Revista Brasileira de Sementes, v.30, n.3, p.104-114, 2008. http://www.scielo.br/scielo.php?script=sci arttext\&pid=S0101-31222008000300014\&lng=pt\&nrm=iso.

SILVA, K.B.; ALVES, E.U.; BRUNO, R.L.A.; MATOS, V.P. Caracterização morfológica de frutos, sementes e germinação de Sideroxylon obtusifolium (Roem. e Schult.) Penn. (SAPOTACEAE). Revista Árvore, v.36, n.1, p.5964, 2012. http://www.scielo.br/scielo.php?script=sci_arttext\&pid=S0100$67622012000100007 \& \operatorname{lng}=$ en\&nrm $=$ iso.

STEFENON, V.M.; GAILING, O.; FINKELDEY, R. Genetic structure of plantations and the conservation of genetic resources of Brazilian pine (Araucaria angustifolia). Forest Ecology and Management, v.255, n.7, p.2718-2725, 2008. http://www.sciencedirect.com/science/article/pii/s0378112708000996

STUMPF, E.R.T.; BARBIERI, R.L.; HEIDEN, G. Cores e formas no Bioma Pampa: Plantas ornamentais nativas. Pelotas: Embrapa Clima Temperado, 2009. 276p. 